\title{
The Legal Definition of Death and the Right to Life
}

\author{
Elizabeth Wicks
}

\section{INTRODUCTION}

The law engages with the issue of death in various manners and contexts. For example, criminal law prohibits killing; inheritance law regulates the redistribution of property after death; and medical law determines when a patient should receive life-sustaining treatment, as well as when a body's organs become available for transplantation purposes. The law provides regulation and clarity to the life-death boundary. It is greatly influenced, however, by clinical, social, and moral conceptions of death and dying. Indeed, the legal definition of death in the UK is merely the judicial application of the current medical definition of death. In this chapter, the relationship between the legal definition of death and the legal protection of a right to life in human rights law will be considered in order to provide some legal perspectives on the eternally challenging question of "when is death?"

E. Wicks $(\square)$

University of Leicester, University Rd, Leicester LE1 7RH, UK e-mail: eaw19@leicester.ac.uk

(C) The Author(s) 2017

S. McCorristine (ed.), Interdisciplinary Perspectives on Mortality and its Timings, Palgrave Historical Studies in the Criminal Corpse and its Afterlife, DOI 10.1057/978-1-137-58328-4_8 


\section{The Legal Definition of Death}

There is often perceived to be a clear distinction between life and death. Indeed, it is the most fundamental distinction in the experience of humanity. In reality, however, the line is blurred. In traditional biological understandings, death occurs when an individual ceases breathing or when his or her heart stops beating. Such cardio-respiratory failure is no longer an adequate conception of death, however, because advances in medical technology have enabled the restarting of a heart that has stopped beating, as well as artificial respiration to counter a cessation in breathing independently. The consequence of this is that a person who would once have been regarded as dead-one who is not breathing and/or whose heart is not beating - can now be revived. Death, in the sense of cardio-respiratory failure, has been conquered. And yet, death remains.

From a legal perspective, such ambiguity is unsatisfactory. The line between life and death must be differentiated for a variety of social and legal reasons. The availability of organs for transplant, rules of inheritance, criminal liability for causing death, and the need for disposal of the body are all issues necessitating a clear line between life and death. There needs to be a clear-cut, and unambiguous, definition of death within the law because legally we treat a dead body very differently from the way we treat a living person.

The law's response to the indeterminacy of cardio-respiratory failure has been a focus upon the death of the brain. A committee of the Harvard Medical School in 1968 first offered a set of criteria by which doctors could establish that a patient had suffered permanent loss of all brain functions. Significantly, the Committee also proposed those criteria as a diagnosis of death. ${ }^{1}$ Subsequently the United States adopted a uniform model death law. The Uniform Determination of Death Act is now law in 36 US states and contains a split legal standard: both cardio-respiratory failure and whole-brain death are regarded as legal death in these jurisdictions. This does not, of course, mean that there are two different ways to die in the US today. Rather, it means that there are two different ways for doctors to determine that somebody has died. The brain death variation avoids any possibility of subsequent medical intervention; once a brain has died, there is no known treatment for revival.

The whole-brain death criteria has been somewhat modified within the UK where both the clinical and legal emphasis is on brain stem 
death. The brain stem's functions include responsibility for generating the capacity for consciousness and the respiratory centre. Significantly, it is also the part of the brain least effected by a lack of oxygen and; therefore, it can be assumed that if the brain stem is irreversibly destroyed by a lack of oxygen, so too are the other parts of the brain. Brain stem death (BSD) has been accepted by the courts in the UK as the legal definition of death. This was first apparent in the case of Re A (1992) 3 Med.L.R. 303 involving a young boy taken to hospital with head injuries suggesting a non-accidental injury. He was placed on a ventilator, but was subsequently declared brain stem dead. His parents wanted him to be maintained on the ventilator to enable their own experts to examine him in the light of potential legal proceedings. The court refused, however, holding that the boy was legally dead and the doctors would not be acting unlawfully by disconnecting the ventilator. This judicial acceptance of BSD as legal death was subsequently confirmed by the House of Lords in Airedale NHS Trust v Bland [1993] I All ER 831, a case concerning a young man-Anthony Bland-who suffered severe brain damage in the Hillsborough disaster and was left in a persistent vegetative state (PVS). The Law Lords confirmed that this man was still legally alive. Lord Keith, for example, said that "In the eyes of the medical world and of the law a person is not clinically dead so long as the brain stem retains its function". ${ }^{2}$

It seems clear that BSD is accepted as the legal definition of death in the UK. Globally, a focus on the brain in defining death has broad acceptance, although some cultures, including Orthodox Jewish, Native American, and Japanese cultures reject it. ${ }^{3}$ Typically, this rejection is founded upon a discomfort in regarding someone as dead if he or she is still breathing, whether artificially assisted or not. Perhaps for the same reason, brain stem death is not without its critics even in societies which have accepted the brain death concept, many of whom argue that it is counter-intuitive to classify an individual with a heartbeat as dead. ${ }^{4}$ This view implies that the law currently regards a dying patient as already dead. If true, this would be a serious encroachment into any ethical or legal protection of life, such as through a right to life. However, as destruction of the brain stem is irreversible and the last part of the brain to be effected by a lack of oxygen, most, including the medical profession, judge BSD as a sign of death rather than dying. There are also some commentators who oppose BSD from the opposite perspective, arguing that we should go further and accept the concept of higher-brain death. 


\section{Higher-Brain Death: Its Proponents and Problems}

Proponents of higher-brain death argue that it is the irreversible loss of consciousness which signifies the end of life. An example of such a loss is a patient in persistent vegetative state (PVS). This condition entails irreversible damage to the higher brain when the brain stem is still functioning. The normal functioning of the brain stem means that the patient may be breathing independently, but the destruction of other parts of the brain means that the patient will have no awareness or consciousness of the world around him or her. It is the tragic condition suffered by Anthony Bland in the Hillsborough disaster and has challenged the courts many times since then. The PVS condition therefore poses considerable ethical and legal dilemmas across the world. PVS patients do not meet the criteria for either whole brain death or brain stem death but everything that made that patient a person has gone: memories, the ability to communicate, conscious awareness. Is this patient really still alive, or is death of the person that he or she used to be a sufficient criterion for the end of life?

Even in the Bland case mentioned above, some judges are uncomfortable with leaving the issue at an unambiguous acknowledgment of the patient being alive. Lord Goff, for example, raises a doubt about this conclusion when he states that the patient's condition "is such that it can be described as a living death". ${ }^{5}$ He proceeds to outline the reason for the introduction of the BSD concept, explaining that "because, as a result of developments in modern medical technology, doctors no longer associate death exclusively with breathing and heartbeat". This, however, is a misleading diversion because in the traditional cardio-respiratory definition of death, Bland is also still alive because he is clearly still breathing. The "living death" concept introduced by Lord Goff seems to underlie many of the judgments and adds unnecessary ambiguity to the legal situation. Hoffmann LJ in the Court of Appeal fell into the same trap, confusingly stating that the patient's "body is alive but he has no life". ${ }^{6}$ While these judicial comments raise concerns about the full extent of the law's protection for a human life in the "twilight zone" between life and death, the judges were not advocating a change in the legal definition of death. Some commentators do, however, adopt such an approach.

For such commentators, patients in PVS are already dead due to the loss of their higher brain functions, even though their body lives on. 
Jeff McMahan, for example, argues that this organism should be treated as a dead body because:

a mere organism does not have interests and cannot itself be benefited or harmed. To end its life is no more objectionable than it is to kill a plant, provided that what is done does not contravene the posthumous interests of, or manifest disrespect for, the person who once animated the organism. $^{7}$

Such an approach makes a clear distinction between the "person" and the "organism" and, as such, is part of a broader ethical movement to distinguish between a person and a human being. The so-called "personhood theory" proposes that not all human beings are "persons" with rights. Although the exact requirements of personhood tend to vary between writers, they all focus on a disembodied mind. Consciousness is widely regarded as a minimum characteristic, and other proposed criteria include capacity for reason, ${ }^{8}$ capacity to value one's own existence, ${ }^{9}$ and moral agency. ${ }^{10}$

Personhood theory's focus only on a person with some degree of capacity takes the "Cartesian" model to its extreme manifestation. The seventeenth-century philosopher René Descartes explains reality as consisting of only res extensa (encompassing the corporeal body) and res cogitans (encompassing the mind). Not only are the body and mind thus distinct under Cartesian dualism, but the body is also subordinated to the mind, meaning that cognitive rationalisation dominates. Indeed, both Kant and Locke utilise a concept of a dominant mind over a mechanized body in order to establish a focus on rationalism. Unfortunately, the dominance of the rational mind over the emotional body under Cartesian dualism has gender-specific implications. As Shildrick notes, women are traditionally viewed as more intimately associated with their bodies and as "intrinsically unable to transcend them". "1 For example, hormones, PMT, pregnancy, menopause, "hysteria", and anorexia are just some of the ways in which a woman's body has, over the centuries, been regarded as affecting her rational mind. If a person is morally valuable because of the dominance of a rational mind over an unreliable body, women may face greater hurdles in maintaining and proving that distinction.

A further significant problem with the personhood theory is that it either includes other species within the concept of personhood (not 
necessarily objectionable in itself but requiring significant changes to our treatment of other species) or it excludes many human beings, including neonates and PVS patients. Proponents of the personhood theory, such as Peter Singer and John Harris, seem to be comfortable with excluding these categories of human beings from personhood, and thus from moral status. However, this does not sit easily with a human rights perspective. International human rights law places great value on underlying principles, such as equality of rights and respect for human dignity. Indeed, the underlying principle of human rights law is that all human beings are entitled to the same fundamental rights due to their status as human beings, regardless of distinctions such as nationality, race or gender. While very few human rights are absolute in their legal protection (and thus, for example, can be infringed where it is proportionate and necessary to do so), they do have universal application. The exclusion of a category of human beings from the protection of human rights law due to a particular physical or mental characteristic of those individuals is irreconcilable with equality of rights. Of course, if those individuals are no longer living human beings, they would not be entitled to equal protection with the living. The (legal) line between life and death is thus fundamental.

\section{Death And the Right to Life}

Every human being has a legally enforceable right to life. This right can be found, for example, in Article 2 of the European Convention of Human Rights (ECHR) and Article 6 of the International Covenant of Civil and Political Rights. Article 2 ECHR is also protected in domestic law by means of the Human Rights Act 1998. This does not, of course, mean that we can require our government to keep us alive indefinitely. It is an inherent fact of life that we will all die. Nonetheless, the right to life does impose a variety of obligations on the state. At its core, the right to life prohibits unjustified killing by the state. However, increasingly its interpretation requires far more than that core minimum, including positive obligations to take appropriate steps to safeguard the lives of those within its jurisdiction.

In Osman v United Kingdom (1998) 29 E.H.R.R. 245; Reps 1998VIII at para 115, the European Court of Human Rights held that Article 2(1) "enjoins the state not only to refrain from the intentional and unlawful taking of life, but also to take appropriate steps to safeguard the lives of those within its jurisdiction". This means that state 
authorities must do all that could reasonably be expected of them to avoid a real and immediate risk to life of which they have, or ought to have, knowledge, although the Court did recognise that this obligation must be interpreted in a way which does not impose an impossible or disproportionate burden on the authorities. ${ }^{12}$ A government committed to the right to life must, therefore, not merely refrain from killing, but also govern in a manner that seeks to preserve human life wherever reasonably possible. Arguably, the most important principle underlying the right to life is not the sanctity of life but rather a requirement of respect for all human life. ${ }^{13}$

The right to life protects all living human beings (with some lingering ambiguity about its application before birth (Vo v France (App. 53924/00), 8 July 2004 [GC], (2005) 40 EHRR 259, ECHR 2004VIII). As discussed above, under the BSD definition of death, that includes patients in PVS whose brain stem continues to function even if the aspects of their higher brains which made them who they were have been destroyed. Does the state have an obligation under the right to life to maintain the life of patients in PVS? It would appear not. The landmark English case of Airedale NHS Trust $v$ Bland confirmed that it is lawful to withdraw life-sustaining treatment (commonly artificial nutrition and hydration (ANH)) from a patient in PVS. The key to the legality of such a course of action is that it is no longer regarded as in the best interests of a patient in PVS to receive the life-sustaining treatment. In the absence of patient consent, medical treatment can only be provided if it is in the best interests of the patient. The best interests test was developed at common law in a very different context (non-therapeutic sterilisations) but is now at the core of the statutory regulation of persons who lack capacity. Section 4 of the Mental Capacity Act 2005 requires that all decisions about persons lacking capacity are taken in their best interests and includes a checklist of factors to be taken into account in determining that. When applied to a patient in PVS, this means that a decision has to be taken whether continued treatment (usually comprising $\mathrm{ANH}$ ) is in the patient's best interests and, if it is not, then it must (rather than may) be withdrawn. Under the Mental Capacity Act, the best interests test is more patient-focused than before, with a requirement to take into account the patient's own past wishes and feelings, values and beliefs, rather than merely medical evidence as to prognosis. The latter is still likely to be very significant, however, and thus it is still not an entirely subjective test of interests. In Bland, the Law Lords were adamant that the relevant question was whether treatment is in the patient's 
best interests rather than whether death is in the patient's best interests but, given that a withdrawal of life-sustaining treatment will inevitably cause death, this is a somewhat meaningless distinction.

The Bland case was decided before the enactment of the Human Rights Act 1998 (HRA) and thus the court gave no weight to issues of patient rights, including the right to life. However, subsequent to the HRA's coming into force, the courts have sought to reconcile the Bland judgment with the right to life. In NHS Trust $A v$ M; NHS Trust $B v$ $H$ [2001] I All ER 801, Butler-Sloss LJ explained that there is no violation of Article 2 ECHR's right to life when life-sustaining treatment is withdrawn because it is no longer in the patient's best interests. This approach to interpretation of Article 2 seems to have been plucked from thin air given that there is no precedent for reading the state's obligations under Article 2 as subject to a best interest determination. In terms of the right to life, this may look suspiciously like we have a right to life until it is not in our best interests to continue living. While this may be a sensible, even justifiable, approach in the context of PVS patients, it is surely worrying in more general terms? Who is to decide when our lives are no longer in our best interests? And how will they know?

The withdrawal of medical treatment leading to death needs to be acknowledged as a legitimate exception to the right to life, but it is a pity that more explicit reasoning has not yet been provided to reconcile the right to life with end-of-life decision-making. As the state is only ever obliged to take reasonable steps to preserve life, it may be that a focus upon both autonomy and quality of life could cast a clearer light upon when it is no longer reasonable to preserve a life. Even in the context of a PVS patient, however, the right to life and other human rights do still have meaning and value. A doctor might be able to withdraw treatment to allow the patient to die, but it would not be lawful for a hospital intruder to shoot the patient in the head, nor for the hospital to throw the patient out onto the street. We would not accept a degrading use of the patient's body even though he is not aware of it. Thus, we do still value this human being - and the law does too. It is a living person, not just an empty shell, or an organism which the "person" has vacated.

\section{Life, Death, and Embodied Selves}

The most objectionable element of the personhood theory's approach, discussed above, is that it does not regard patients in PVS (or indeed many other living human beings) as persons with moral value. 
Personhood theory entirely overlooks the value of the human body in its rush to remove rights from PVS patients. By contrast, embodiment theory focuses upon the whole person as a union of body and mind. ${ }^{14}$ It recognises the interaction and relationship between our mental selves and our bodies, and gives value to the body in contrast with the traditional division of body and mind under Cartesian dualism, which views the body as little more than a machine. A focus on the embodied self would put the body back into the equation and, in relation to the definition of death, would rule out any move towards higher brain death.

As noted above, higher-brain death proponents view a living body devoid of the mind as already deceased. This is in stark contrast to an embodiment approach which views both body and mind as crucial to moral status and legal respect. As Martin Pernick explains, the "controversy between advocates of whole-brain and higher-brain criteria for diagnosing brain death often reflected a much older conceptual contest over whether mental activity or bodily integration constituted the essence of human life". ${ }^{15}$ Advocates of higher-brain death recognise only the human mind and not the human body as being morally valuable. As such, this definition of death would rest upon a concept of the disembodied self. It connects naturally with personhood theory which similarly affords respect to the mind as distinct from the body. Indeed, as Harris confirms, under the personhood theory, persons need not be organic life forms at all. ${ }^{16}$

So, what of an organic life form devoid of a functioning mind? Is it conceivable that a deceased person residing in a living body could be buried or cremated? This is the inevitable consequence of both personhood and higher-brain death theories. Lizza explains why it is not an insurmountable hurdle for him as he regards the continuation of the organism that once constituted the person as a non-critical issue, arguing that mere organic integration is insufficient for the continued life of a person. ${ }^{17}$ By distinguishing between the life of the person and the life of the human organism, Lizza is able to envisage the burial of a living and breathing human body: "Instead of a person's death resulting in remains in the form of an inanimate corpse, a person's remains can now take the form of a living being devoid of the capacity for consciousness and any other mental function". ${ }^{18}$ Such an approach has so far deviated from legal concepts of human rights and human dignity as to be irreconcilable with existing international and national law commitments to human rights law, as well as ethical and moral obligations to humankind. The law unsurprisingly rejects such an artificial distinction between deceased 
persons and living human bodies and instead, as explained above, regards the irreversible death of the brain (or brain stem) as the point of death. At this stage, and not before, legal obligations to respect the rights of a human being cease. Thus the right to life, and the (albeit limited) protection it affords, ends only when life itself has ended.

The question of why human life is protected in the first place-why human life matters - seems to be closely tied to the concept of consciousness. The higher level of consciousness enjoyed by humans as compared to many other species is, arguably, the underlying reason why human life should be regarded as more valuable and given greater protection, morally and legally, than the life of a virus or a plant or an animal. ${ }^{19}$ There is not, as yet, any clear explanation for how consciousness arises or why, although there is an indisputable link with electrical brain activity. As Merlin Donald explains, "conscious effort is the single most reliable predictor of the patterns of brain activity". ${ }^{20}$ However, science still cannot tell us why this is so: "Brains that pulse with certain patterns of electrical activity are conscious. Why? They just are". ${ }^{21}$ Human life matters, it is argued, because of human consciousness. ${ }^{22}$ But this does not inevitably lead to the personhood theory's controversial approach of excluding certain human beings from moral status and legal protection due to their loss of a characteristic such as consciousness. If human life matters, then it always matters, regardless of personhood, rationality, moral agency, capacity or consciousness. The life of an individual human being matters not because that organism is sentient or rational (or free of pain, or values its own existence) but because it is a human life. ${ }^{23}$ This point is supported by the ethical and legal principle of equality which is well established in the field of human rights. A core requirement for an individual human being to be regarded as possessing a life may be regarded as basic integrative functioning of the organism. In other words, (from viability) until brain death, while a human organism has the potential to function in an integrative manner, an individual has a life equal to that of all other human organisms. In terms of defining death, this means that life ends only when the human organism - the body and mind together-dies. This cannot sensibly require the death of all of the body's cells, but rather the death of the organism as a whole. In other words, life comes to an end when the integrative action between the organs of the body is irreversibly lost. The death of the brain, or the brain stem, is one, and perhaps currently the best, means of discerning that end. It is fitting, therefore, that the law has adopted this stage for the legal definition of death. 


\section{CONCLUSION}

The law has a crucial role in regulating issues of life and death. In addition to its essential role in clarifying legal responsibilities, it is an important influence on social and ethical perspectives regarding the inevitable endpoint of life. Furthermore, the entire concept of human rights law is based around the idea that all human beings are entitled to equal legal protection for a range of rights and freedoms, thus necessitating an unambiguous dividing line between a rights-holder and a deceased body. Death is not unambiguous, however, at least not in its appearance to modern medical technology and understanding of the human mind and body. The point at which the law draws the line between life and death, or more specifically between dying and death, is always likely to be controversial. The contemporary focus on the irreversible destruction of the brain-brain stem death in the UK-builds upon the current state of medical technology and its ability to revive certain parts of the human body. It also fits well with an embodiment approach to valuing human life which strives to include both mind and body within conceptions of the person and moral status. The alternative, albeit increasingly influential, personhood theory, with its singular emphasis upon the mind, would lend support to a different conception of death: one that hinges upon the destruction of the higher-brain and certain mental capacities. As tragic as such a transformation in life can be, it is not appropriately regarded as a death of a human being, and to label it a death of a person is dangerously misleading. We are not just our minds, but also our bodies, which serve as our homes, our transport, our clothing, our identities. ${ }^{24}$ They are also inevitably our ultimate cause of death, for we will not survive the loss of our bodies. This focus on the embodied self does not necessitate a striving to sustain all permanently comatose human lives. The withdrawal of life-sustaining treatment is not only lawful under specific circumstances, but is also sometimes ethically appropriate, morally good, and respectful of the human being's rights. But let us never forget, or worse ignore, that the human being who has lost so much of what made her an individual, is still alive and entitled to a right to life; a right that is always limited, both in terms of state obligations and its application to mortal beings. 


\section{Notes}

1. "A Definition of Irreversible Coma: Report of the Ad Hoc Committee of the Harvard Medical School to Examine the Definition of Brain Death", Journal of American Medical Association, 205 (1968), p. 337.

2. Airedale NHS Trust v Bland [1993] 1 All ER 831, p. 859.

3. See David Novak, The Sanctity of Human Life (Washington, D.C., 2007); Noel Williams, The Right to Life in Japan (London, 1997); Clive Lawton, "Judaism". In Clive Lawton and Peggy Morgan, Ethical Issues in Six Religious Traditions (Edinburgh, 2007).

4. See Martyn Evans, "Against the Definition of Brainstem Death". In Robert Lee and Derek Morgan eds., Death Rites: Law and Ethics at the End of Life (London, 1994), pp. 1-10.

5. Bland, p. 865 .

6. Ibid., p. 850 .

7. Jeff McMahan, "Brain Death, Cortical Death and Persistent Vegetative State". In Helga Kuhse and Peter Singer eds., A Companion to Bioethics (Oxford, 1998), p. 258.

8. See Peter Singer, Rethinking Life and Death: The Collapse of Our Traditional Ethics (Oxford, 1995).

9. See John Harris, The Value of Life: An Introduction to Medical Ethics (London, 1985).

10. See Immanuel Kant, Groundwork of the Metaphysics of Morals, Lawrence Pasternack ed., (London, 2002).

11. Margrit Shildrick, Leaky Bodies and Boundaries: Feminism, Postmodernism and (Bio) Ethics (London, 1994), p. 26.

12. Osman v United Kingdom (1998) 29 E.H.R.R. 245, para 116.

13. Elizabeth Wicks, "The Meaning of Life: Dignity and the Right to Life in International Human Rights Treaties", Human Rights Law Review, 12 (2012), p.199.

14. Alistair V. Campbell, The Body in Bioethics (London, 2009), p. 4.

15. Martin S. Pernick, "Brain Death in a Cultural Context: The Reconstruction of Death 1967-1981". In Stuart J. Youngner, Robert M. Arnold, and Renie Schapiro eds., The Definition of Death: Contemporary Controversies (Baltimore, 1999), p. 12.

16. John Harris, "The Right to Die Lives! There is No Personhood Paradox", Medical Law Review, 13 (2005), p. 389.

17. John P. Lizza, Persons, Humanity and the Definition of Death (Baltimore, 2006), p. 13.

18. Ibid., p. 15.

19. See Elizabeth Wicks, The Right to Life and Conflicting Interests (Oxford, 2010). 
20. Merlin Donald, A Mind So Rare: The Evolution of Human Consciousness (New York, 2001), p. 178.

21. Ibid.

22. See Wicks, The Right to Life.

23. Ibid., p. 16.

24. See Elizabeth Wicks, The State and the Body: Legal Regulation of Bodily Autonomy (London, 2016).

\section{Author Biography}

Elizabeth Wicks is a Professor of Human Rights Law in the Leicester Law School at the University of Leicester. Her main research interest is in human rights in healthcare. Her latest book, The State and the Body: Legal Regulation of Bodily Autonomy, was published by Hart in 2016.

Open Access This chapter is licensed under the terms of the Creative Commons Attribution 4.0 International License (http://creativecommons.org/licenses/ by $/ 4.0 /)$, which permits use, sharing, adaptation, distribution and reproduction in any medium or format, as long as you give appropriate credit to the original author(s) and the source, provide a link to the Creative Commons license and indicate if changes were made.

The images or other third party material in this chapter are included in the chapter's Creative Commons license, unless indicated otherwise in a credit line to the material. If material is not included in the chapter's Creative Commons license and your intended use is not permitted by statutory regulation or exceeds the permitted use, you will need to obtain permission directly from the copyright holder.

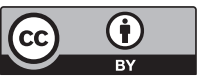

